\title{
Field clearance of an intertidal bivalve bed: relative significance of the co-occurring blue mussel Mytilus edulis and Pacific oyster Crassostrea gigas
}

\author{
Bent Vismann ${ }^{1, *}$, Mark Wejlemann Holm ${ }^{2}$, Jens Kristian Davids ${ }^{2}$, Per Dolmer ${ }^{3,4}$, \\ Morten Foldager Pedersen ${ }^{2}$, Elisa Blanda ${ }^{2}$, Helle Torp Christensen ${ }^{3,5}$, \\ Pernille Nielsen ${ }^{1,6}$, Benni Winding Hansen ${ }^{2}$
}

\author{
${ }^{1}$ Marine Biological Section, University of Copenhagen, Strandpromenaden 5, 3000 Helsingør, Denmark \\ ${ }^{2}$ Department of Science and Environment, Roskilde University, Universitetsvej 1, 4000 Roskilde, Denmark \\ ${ }^{3}$ National Institute of Aquatic Resources, Danish Technical University, Jægersborg Allé 1, 2920 Charlottenlund, Denmark \\ ${ }^{4}$ Present address: Orbicon, Jens Juuls Vej 16, 8260 Viby, Denmark \\ ${ }^{5}$ Present address: Greenland Institute of Natural Resources, Kivioq 2, 3900 Nuuk, Greenland \\ ${ }^{6}$ Present address: National Institute of Aquatic Resources, Danish Technical University, Jægersborg Allé 1, \\ 2920 Charlottenlund, Denmark
}

\begin{abstract}
At an approximately $12000 \mathrm{~m}^{2}$ sheltered intertidal bivalve bed in the western part of the Limfjord, Denmark, the Pacific oyster Crassostrea gigas co-occurs with the blue mussel Mytilus edulis. The relative significance of the impact of the 2 species on phytoplankton density during a tidal cycle was estimated by combining field measurements of clearance rates and modelling of the bivalve bed (topography, biomass distribution, temporal and spatial water coverage and depth). The average density of $C$. gigas and $M$. edulis was $35 \pm 36$ and $1001 \pm 685$ ind. $\mathrm{m}^{-2}$, respectively. The water volume cleared during a tidal cycle was estimated at $45838 \mathrm{~m}^{3}$, of which C. gigas and $M$. edulis contributed 9169 and $36669 \mathrm{~m}^{3}$, respectively. Therefore, M. edulis contributed 4 times as much as C. gigas to the bivalve bed's clearance, and the 2 bivalves were estimated to clear the water volume 1.9 times during each tidal cycle. However, the estimated water column cleared during low tide is overestimated due to phytoplankton depletion. Hence, it is concluded that the bivalve bed clears the water close to 1 time each tidal cycle. This, together with a low dry weight of soft parts, indicates that the bivalve bed, in general, is food-limited.
\end{abstract}

KEY WORDS: Crassostrea gigas - Mytilus edulis · Clearance rate · Field measurements · Feeding activity $\cdot$ Intertidal bivalve bed

\section{INTRODUCTION}

Benthic suspension feeders are of paramount importance for the benthic-pelagic coupling in coastal ecosystems (Seed 1976, Dame et al. 1991, Gili \& Coma 1998, Beadman et al. 2004). Their capacity to remove seston from the water column is essential for the energy flow in the ecosystem. In eutrophic

\footnotetext{
${ }^{*}$ Corresponding author: bvismann@bio.ku.dk
}

shallow-water estuaries, benthic suspension feeders can compromise up to $95 \%$ of the total benthic fauna biomass (Conley et al. 2000). If water current, wind and waves provide sufficient mixing of the water column, the seston will be available for the benthic suspension feeders (Dame \& Prins 1997, Riisgård et al. 2007), and in such situations, the suspension feeders may control the phytoplankton biomass (Cloern

(C) The authors 2016. Open Access under Creative Commons by Attribution Licence. Use, distribution and reproduction are unrestricted. Authors and original publication must be credited. 
1982). However, in cases of insufficient mixing, the benthic suspension feeders cannot realize their potential grazing impact on the phytoplankton (Koseff et al. 1993, Møhlenberg 1995). Besides availability, algal concentration is an important parameter for suspension feeding, as, at both low and high algal concentrations, bivalves have been shown to reduce suspension feeding due to partial closure of their valves (e.g. Riisgård \& Randløv 1981, Riisgård 1991, Dolmer 2000a,b, Strohmeier et al. 2009).

The blue mussel Mytilus edulis (Linnaeus, 1758) is a prominent suspension feeder and a key species for the benthic-pelagic coupling in many coastal areas. In intertidal zones with high lateral advection, such as the Dutch, German and Danish Wadden Sea, the seston supplied to these high-energy systems allows M. edulis to form dense beds (van de Koppel et al. 2008). Within recent years, the non-indigenous Pacific oyster Crassostrea gigas (Thunberg, 1793) has spread from intertidal aquaculture sites along the western coast of northern Europe (Nehls et al. 2009, Troost 2010). C. gigas larvae settle on hard substrate, and as $M$. edulis beds are considered the prevailing hard substrate in these soft-sediment intertidal areas, $C$. gigas settles initially on $M$. edulis beds (Reise 1998, Wehrmann et al. 2000, Markert et al. 2010). As a consequence, the native $M$. edulis and $C$. gigas are in direct competition for both food and space (Nehls et al. 2009). In the Wadden Sea area, this has so far led to a conversion of a large part of $M$. edulis beds into C. gigas reefs due to the exponential growth of the $C$. gigas population (Diederich et al. 2005). However, no evidence of $C$. gigas completely outcompeting native bivalves has been found (Troost 2010, Holm et al. 2016), and in sheltered estuaries, C. gigas can be present in the intertidal zone at moderate densities without showing a significant expansion in population density (sensu Reise et al. 2006) and apparently so far in co-occurrence with $M$. edulis (Wrange et al. 2010, Holm et al. 2015, 2016).

$M$. edulis has a dry weight-specific clearance rate of about $7.5 \mathrm{l} \mathrm{h}^{-1} \mathrm{~g}^{-1}$ (at 10 to $15^{\circ} \mathrm{C}$ ) (Møhlenberg \& Riisgård 1979, Riisgård \& Møhlenberg 1979). The dry weight-specific clearance rate of $C$. gigas is in the range of 3 to $6 \mathrm{l} \mathrm{h}^{-1} \mathrm{~g}^{-1}$ at water temperatures of 15 to $19^{\circ} \mathrm{C}$ (Bougrier et al. 1995, Haure et al. 2003) and 12 to $17 \mathrm{l} \mathrm{h}^{-1} \mathrm{~g}^{-1}$ at $25^{\circ} \mathrm{C}$ (Dupuy et al. 2000). Walne (1972) found the dry weight-specific clearance rate $\left(\approx 21^{\circ} \mathrm{C}\right)$ of $C$. gigas and $M$. edulis to be 9.1 and 3.71 $\mathrm{h}^{-1} \mathrm{~g}^{-1}$, respectively. Also, in similar-sized specimens, Troost et al. (2009) found no significant difference in feeding efficiency between the 2 bivalve species. The maximum adult shell height measured from the umbo of $M$. edulis is about $7 \mathrm{~cm}$; for $C$. gigas, it is normally 8 to $20 \mathrm{~cm}$, but exceptionally large specimens can reach 30 to $40 \mathrm{~cm}$ (Nehring 2006). Hence, being a much larger animal and projecting higher up into the water column than $M$. edulis, $C$. gigas could have a competitive advantage in relation to access to food, as suggested by Diederich (2006).

Field measurements of suspension-feeding bivalves, as pointed out by, for example, Beninger (2009) are highly needed because the role of suspension feeders in nature is difficult to elucidate from physiological laboratory studies, which are typically made at the level of individuals using algal monocultures. The ecological effect of the 2 species has to be addressed at the population-level and in the field. First, it will depend on the present biomass of the 2 species (i.e. size and density of species in the area). Second, in nature, bivalves feed on a mixture of different algal species and other organic and inorganic particles, upon which $C$. gigas and $M$. edulis, along with other bivalve species, have been shown to perform preferential capture and absorption mediated by extrinsic as well as intrinsic factors (Shumway et al. 1985, Ward \& Shumway 2004, Beninger et al. 2008, Pales Espinosa et al. 2010). In addition, in dense bivalve beds, inter- and intraspecific interactions may cause cascade effects (e.g. shell closure), affecting the overall suspension-feeding capacity of the population. In field studies of clearance rates, several techniques have been used (e.g. Vismann 1990, Prins et al. 1996, Cranford \& Hill 1999, Dolmer 2000b, Pouvreau et al. 2000, Grizzle et al. 2006, Saurel et al. 2007, Hansen et al. 2011). In the present study, we used the technique developed by Hansen et al. (2011) to study the clearance rate of populations of $C$. gigas and $M$. edulis in the intertidal zone of a sheltered bivalve bed. Our study site is characterized by very low tidal current and small tidal amplitude, resulting in limited daily renewal of particulate food for the grazers. Hence, the bivalves are hypothesized to be food-limited. The aims of the present study were to estimate the population (areaspecific) feeding activity and to compare clearance rates of $C$. gigas and $M$. edulis to estimate their integrated impact on the phytoplankton during a tidal cycle. The above objectives were achieved by combining measured clearance rates with detailed modeling of the bivalve bed topography, spatial biomass distribution and temporal water coverage. The results are discussed in terms of species' responses to the environment and realized bivalve bed clearance in relation to their theoretical clearance potential. 


\section{MATERIALS AND METHODS}

\section{Study area}

The present study was conducted on a bivalve bed of co-occurring populations of Crassostrea gigas and Mytilus edulis located in a sheltered intertidal area off Agger Tange in the western part of the Limfjord, Denmark (56 $\left.43.3^{\prime} \mathrm{N}, 8^{\circ} 15.4^{\prime} \mathrm{E}\right)$ (Fig. 1). The bank area (approximately $12000 \mathrm{~m}^{2}$ ) is characterized by very low tidal current and small peak-to-peak amplitude. C. gigas was introduced in the area for aquaculture purposes for a couple of years in the early 1970s (Jensen \& Knudsen 2005) and has since been present in moderate densities (Holm et al. 2015, 2016). Data were collected during field expeditions in 2009 (17-20 June) and 2010 (31 May-4 June). In 2009, sampling was conducted along 5 transects, each $225 \mathrm{~m}$ long. A sampling grain of $0.25 \mathrm{~m}^{2}$ is commonly utilized in surveys and studies of bivalve beds on sand and mud flats (e.g. Diederich et al. 2005, Kristensen \& Borgstrøm 2005, Nehls et al. 2006, Büttger et al. 2011); thus, this sample grain was adopted in the present study. It was dropped every $15 \mathrm{~m}$ by randomly assigning a direction and distance $(0-10 \mathrm{~m})(\mathrm{n}=106)$.

In 2010, a virtual $40 \times 40 \mathrm{~m}$ grid was superimposed on the study site using GIS software (ESRI ArcMap, version 10.1), and sample points were randomly generated within each grid cell; in addition, 3 smaller fractions of the bivalve bed were sampled to capture small-scale changes $(\mathrm{n}=155)$. Sample points were selected by randomly assigning a direction and dis-

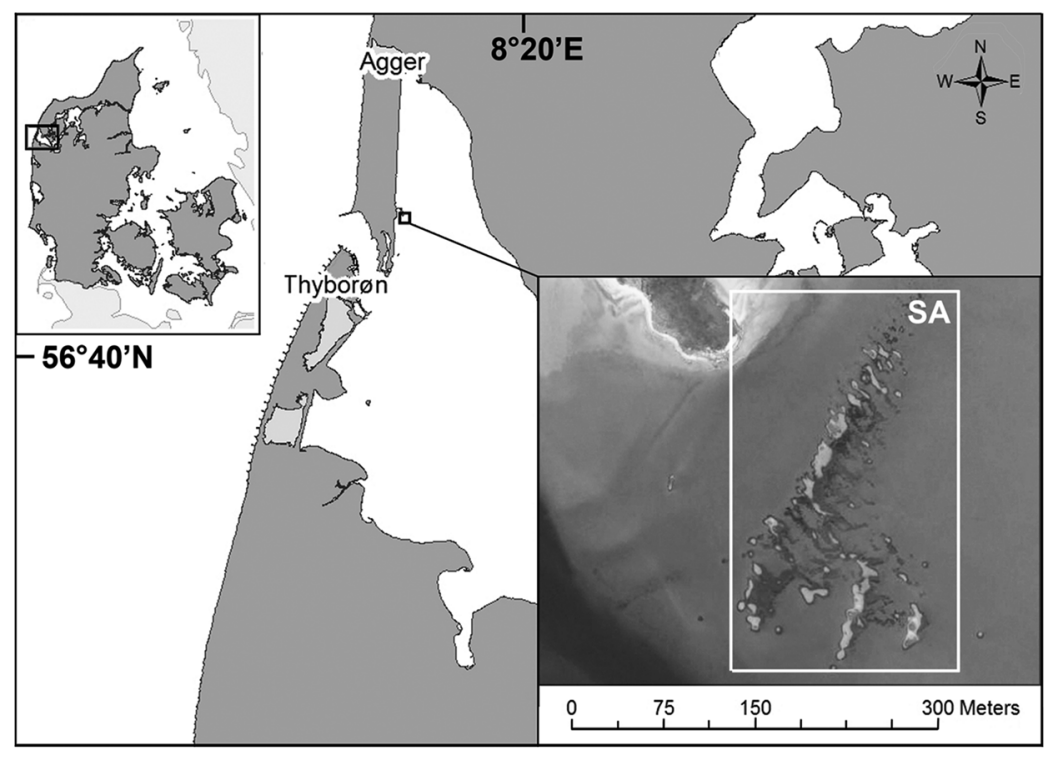

Fig. 1. Study area (SA) off Agger Tange in the western part of the Limfjord estuary, Denmark (56 $\left.43.3^{\prime} \mathrm{N}, 8^{\circ} 15.4^{\prime} \mathrm{E}\right)$ tance every $5 \mathrm{~m}$ in the longitudinal direction of the bivalve beds (Fig. 1). No samples were collected in the northern part of the bivalve bed, as it was used for another experiment. In each sample point, the depth was measured and all bivalves were collected.

\section{Topography of the bivalve bed and temporal water coverage}

The topography and tidally induced change in water coverage of the bivalve bed were modelled based on data from 2010. The depth of the water column (i.e. reference depth) was measured every 10 min for $5 \mathrm{~d}$ using 2 pressure gauges (DST centiTD, Star Oddi). The pressure gauge measurements were calibrated with measurements on a vertically positioned ruler, converting changes in pressure to changes in water depth (linear regression: water depth $[\mathrm{cm}]=893.48 \times$ pressure $[$ bar $]-381.84 ; \mathrm{n}=63$; $\left.\mathrm{r}^{2}=0.93\right)$. The water depth was then adjusted to Danish Vertical Reference 1990 (Bahl 2006) by relating the measurements at Agger Tange with a measuring station at Thyborøn (3.5 km away) and corrected for the temporal delay in the high and low tide peak between the 2 locations (1 h $20 \mathrm{~min}$ ). The water depth was measured across the entire bivalve bed ( $n=155)$. Correcting these measurements according to the reference depth allowed the topography of the bivalve bed to be interpolated (resolution $1 \times 1 \mathrm{~m}$ ) by using the inverse distance weighting (IDW) method with standard GIS software (ESRI ArcMap, version 10.1). Finally, the modelled topography of the bank was combined with the tidally induced oscillation in water depth to determine the temporal emersion and submersion of the bivalve bed.

\section{Bivalve density}

In each sample, all specimens of $C$. gigas and a minimum of approximately 100 specimens of $M$. edulis were randomly collected. In 2010, care was taken not to sample at the same positions (resolution $\pm 3 \mathrm{~m}$ ) which had been sampled in 2009. The density (ind. $\mathrm{m}^{-2}$ ) of C. gigas and M. edulis ( $\mathrm{n}=1028$ and 29519 , respectively) within each sample was recorded. The shell heights of all C. gigas were measured. The shell height of $M$. edulis was measured on 
randomized subsamples. The randomization of $M$. edulis subsamples was achieved by one person making a series of numbered $M$. edulis piles (approx. 100 individuals in each) and a second person picking 2 random numbers corresponding to the piles to be included in the subsamples. All shell heights were measured from the umbo to the longest diameter (nearest millimeter), using an electronic caliper.

\section{Shell height to dry weight of soft parts}

Individuals of $C$. gigas and $M$. edulis (2009: $\mathrm{n}=30$ and 115, respectively; 2010: $\mathrm{n}=180$ and 193, respectively) in each sample taken for bivalve density analysis were randomly subsampled. The randomization of C. gigas subsamples was achieved by one person assigning numbers to all individual $C$. gigas and a second person picking random numbers corresponding to the $C$. gigas to be included in each subsample. The randomization of $M$. edulis subsamples was achieved by one person making a series of numbered $M$. edulis piles (approx. 10 individuals in each) out of 1 unused pile from the shell height measurement and a second person picking random numbers corresponding to the piles to be included in the subsamples. As in many other field studies, we had to freeze $\left(-18^{\circ} \mathrm{C}\right)$ all subsamples prior to our return to the laboratory. Therefore, it should be noted that dry weights in the present study do not represent dry weights as measured from fresh samples. When returned to the laboratory, samples were heated at $105^{\circ} \mathrm{C}$ until constant dry weight (DW, g) (sensu Mo \& Neilson 1994). After drying, samples were allowed to cool in a desiccator for 30 min before dry weight $(\mathrm{g})$ was determined. The allometric coefficient $(b)$ and exponent (a) relating shell height to dry weight of soft parts of the 2 species were analyzed by linear regression analysis on log-transformed data and non-linear regression on raw data to identify the regression model to be used for the conversion of shell heights into dry weight of soft parts (see 'Statistics' in this section).

\section{Spatial distribution of Crassostrea gigas and Mytilus edulis on the bivalve bed}

The present study represents the first attempt to analyse the spatial distribution of $C$. gigas and $M$. edulis at Agger Tange. Therefore, the parameters shaping the spatial distribution of the 2 bivalves are unknown. The density of C. gigas and M. edulis outside the bivalve bed is very low, and it was therefore presumed that water depth is an important parameter in shaping the distribution of the 2 bivalves on the bed. However, a rigorous post hoc analysis would be necessary to refine the data. The present study represents a first attempt to estimate the influence of small tidal fluctuations on a mixed intertidal bivalve bed, using a field indicator of feeding activity.

The area-specific biomass $\left(\mathrm{g} \mathrm{DW} \mathrm{m}^{-2}\right.$ ) for each sampling point, collected in 2010, was calculated using the shell height to dry weight relationships obtained for $C$. gigas. For $M$. edulis, the shell height was determined for a fraction of individuals in a sample point. After estimating the combined biomass of the fraction, the total area-specific biomass was extrapolated for the sampling point. Finally, the biomass of the 2 species in each sample point was interpolated (IDW) to produce biomass estimates (resolution $1 \times 1 \mathrm{~m}$ ) of the 2 species on the bivalve bed.

\section{Clearance rate}

The clearance rates of undisturbed C. gigas or $M$. edulis were measured in the field (2009 and 2010) using the open-top chamber technique developed by Hansen et al. (2011). The open-top chamber was made out of a $49 \mathrm{~cm}$ diameter PVC tube $80 \mathrm{~cm}$ high. At deployment, the chamber was positioned 5 to $10 \mathrm{~cm}$ down in the soft sediment and enclosed 1886 $\mathrm{cm}^{2}$ of soft-sediment seafloor together with the associated fauna and overlying water column. During deployment, the enclosed water was thoroughly mixed by an air lift supplied with compressed air from a SCUBA tank. Fluorescence, temperature and salinity of the enclosed water column were continuously monitored (4 Hz) with a CTD (SBE 19plus, SeaBird Electronics) (for further details, see Hansen et al. 2011). At deployment, the water depth present in the open-top chamber was measured. Depending on ambient tide and wind surge, water depth in the deployments varied from 20 to $40 \mathrm{~cm}$, corresponding to $\sim 40$ to $80 \mathrm{l}$ being enclosed by the chamber. To ensure that only one of the bivalve species was present in the chamber, we either removed the unwanted species or collected the target species and constructed monospecies plots. In the case of the latter, the plot was left for acclimatization for at least $24 \mathrm{~h}$ before deployment of the chamber and initiation of clearance rate measurements.

Fluorescence was used as a proxy for algal concentration, and the decrease in fluorescence over time was used as an indirect estimate of bivalve clearance. In the laboratory, this recording technique has been 
shown to give reliable results (Riisgård 2001, Petersen et al. 2004). However, in the field, seston contains an assembly of different phytoplankton species, which might not all be retained $100 \%$ by bivalves (e.g. picophytoplankton). Proportional to the amount of chlorophyll contained in the picophytoplanktonic fraction, the calculated clearance rates will be more or less underestimated (Williams 1982). In the study area, the proportion of picophytoplankton is low during early spring $(0-4 \%)$, increases to a maximum of $7 \%$ in June and stabilizes at $4 \%$ for the rest of the growth season (H. H. Jakobsen pers. comm.). Therefore, in the present study, the proportion of picophytoplankton present made our estimates to some degree underestimated. In addition, $C$. gigas and $M$. edulis both retain phytoplankton species larger than 4 to $7 \mu \mathrm{m}$ with $100 \%$ efficiency (Møhlenberg \& Riisgård 1978, Barillé et al. 1993, Strohmeier et al. 2012); thus, in the present study, the clearance activity of the 2 species can be compared. In the deployments, the number of individuals present, in relation to the chamber water volume, gave sufficient decreases in fluorescence within 20 to $30 \mathrm{~min}$ for reliable clearance rate calculations (see Hansen et al. 2011). The blank clearance rate in ambient seawater was determined using the decrease in fluorescence as a function of time in 4 deployments without bivalves in the chamber. Individual clearance rate $\left(\mathrm{CR}_{\mathrm{i},}, \mathrm{h}^{-1}\right)$ was calculated according to Coughlan (1969) and corrected for blank clearance rate:

$$
\mathrm{CR}_{\mathrm{i}}=\frac{V}{t \cdot \mathrm{n}} \cdot \ln \left(\frac{C_{0}}{C_{t}}\right)
$$

where $V=$ volume of the chamber (l), $t=$ time of measurement $(\mathrm{h}), \mathrm{n}=$ number of individuals in the chamber and $C_{0}$ and $C_{t}=$ fluorescence $(\mathrm{V})$ at time 0 and $t$ (average fluorescence for the first and last $30 \mathrm{~s}$, i.e. each 120 data points of the deployment).

Because clearance rates vary with temperature, the measurements in each deployment were standardized to the overall mean temperature of the 2 field expeditions $\left(17^{\circ} \mathrm{C}\right)$. The temperature-standardized individual clearance rates $\left(\mathrm{CR}_{\mathrm{it}}, \mathrm{l} \mathrm{h}^{-1}\right)$ were calculated according to the equation:

$$
\mathrm{CR}_{\mathrm{it}}=\mathrm{CR}_{\mathrm{i}} \cdot Q_{10}{ }^{\left(\frac{17-T_{\mathrm{o}}}{10}\right)}
$$

where $Q_{10}=$ temperature coefficient, arbitrarily set to the value 2 ; and $T_{\mathrm{o}}=$ observed mean temperature during each deployment $\left({ }^{\circ} \mathrm{C}\right)$.

After each deployment, the shell height of all bivalves present in the open top chamber was measured using a digital caliper. The mean dry weight of soft parts for each bivalve species was estimated using the appropriate allometric height-to-weight relationships from the present study. To estimate the area-specific clearance rate $\left(\mathrm{CR}_{\text {ita }}, 1 \mathrm{~h} \mathrm{~m}^{-2}\right)$, all clearance rates were standardized to the mean areaspecific density and dry weight of soft parts of the 2 species according to the equation:

$$
\mathrm{CR}_{\text {ita }}=\frac{\mathrm{DW}_{\mathrm{avg}}}{\mathrm{DW}_{\mathrm{o}}} \cdot \mathrm{CR}_{\mathrm{it}} \cdot d
$$

where $\mathrm{DW}_{\mathrm{avg}}=$ mean dry weight of soft parts in the study area $(\mathrm{g}), \mathrm{DW}_{\mathrm{o}}=$ observed mean dry weight of soft parts in the deployment $(\mathrm{g})$, and $d=$ observed average bivalve density in the study area (ind. $\mathrm{m}^{-2}$ ).

\section{Chl $a$ analysis}

During the field expeditions, 10 water samples were taken in triplicate from the well-mixed water column in the open-top chamber. The samples were immediately pressure-filtrated using a $60 \mathrm{ml}$ disposable syringe equipped with a $25 \mathrm{~mm}$ diameter $0.2 \mu \mathrm{m}$ pore size GF/F filter in a filter capsule. The filter was placed in a $20 \mathrm{ml}$ glass scintillation vial filled with $5 \mathrm{ml} \mathrm{96 \%} \mathrm{ethanol} \mathrm{as} \mathrm{the} \mathrm{extraction} \mathrm{sol-}$ vent (sensu Wasmund et al. 2006) and kept in the dark at ambient field temperature (maximum $6 \mathrm{~h}$ ). When returned to the laboratory, the filters were stored at $-20^{\circ} \mathrm{C}$ until further processing some weeks later. The pigment was extracted overnight in $96 \%$ ethanol. The extract was filtrated $(0.2 \mu \mathrm{m}$ pore size), and the chl a concentration was measured spectrophotometrically according to Strickland \& Parsons (1972). Linear regression of the chl a concentration $\left(\mu \mathrm{g} \mathrm{l}^{-1}\right.$ ) and the fluorescence signal $(\mathrm{V})$ recorded by the CTD at the time of water sampling was made. The regression $\left(\mathrm{chl} \mathrm{a}\left[\mathrm{\mu g} \mathrm{l}^{-1}\right]=1.8734 \cdot \mathrm{V}-1.2\left[\mathrm{r}^{2}=\right.\right.$ $0.99 ; \mathrm{n}=10]$ ) was used to convert in situ fluorescence to chl a concentration.

\section{Estimation of the bivalve bed clearance}

The modelled topography of the bank and changes in water depth (in $5 \mathrm{~cm}$ depth intervals) during a tidal cycle were used to estimate the total water volume over the bank ( $1 \mathrm{~h}$ intervals). Combining this with the modelled biomass of the 2 bivalve species gave an estimate of the presence in each water depth interval during a tidal cycle. The estimated total water volume available for the bivalves was calculated for each water depth interval. In the present study, it was not 
possible to collect the extensive data needed to establish a temporal and 3-dimensional spatial model of the development in water movement during a tidal cycle. Therefore, the bivalve bed clearance during a tidal cycle was estimated by assuming that the water covering the bivalve bed area was renewed once each hour. A provisional evaluation of the typical water speeds based on our own observations of horizontal advection of suspended sediment during a tidal cycle was in the range of 0.05 to $0.15 \mathrm{~cm} \mathrm{~s}^{-1}$, which supports the above assumption. The total water volume cleared during a tidal cycle was calculated by summation of the obtained clearance for each time interval.

\section{Statistics}

SigmaPlot 12.5 (Systat Software) was used to check data for normality and homoscedasticity and then together with PAST 3.12 (Hammer et al. 2001) to perform statistical analysis. Mean values of water temperature, salinity and shell height of the 2 bivalve species for each of the 2 sampling years were compared by $t$-tests (temperature and salinity data were normally distributed and variances were homogeneous) or Mann-Whitney $U$-tests (data for shell heights were non-normally distributed and variances were heterogeneous). The mean area-specific clearance activity of the 2 bivalve species was compared by MannWhitney $U$ - tests (data were non-normally distributed and variances were heterogeneous). Linear regressions relating shell height to dry weight followed the procedure recommended by Boldina \& Beninger (2016) to test if the best linear unbiased estimator (BLUE) conditions were fulfilled. The bias on estimated parameters obtained by linear regressions (log-transformed data) was compared to non-linear regressions on raw data with likelihood analyses following Xiao et al. (2011). The effect size of differences in mean values and regression estimators was calculated using Cohen's $D$. Mean values are given with $\pm 1 \mathrm{SD}$, and the significance level for all tests was set at $\alpha=0.05$.

\section{RESULTS}

\section{Environmental parameters}

Mean water temperatures during the 2009 and 2010 field expeditions were $14.8 \pm 0.3$ and $18.5 \pm$ $1.6^{\circ} \mathrm{C}$, respectively, and were significantly different between years ( $t$-test: $\mathrm{p}=0.003, t=-4.727, \mathrm{df}=6$ ).
Daily temperature during the clearance measurements increased in the range of 1.1 to $7.4^{\circ} \mathrm{C}$ due to weather conditions and solar radiation. Mean salinities for the 2 expeditions were $33.5 \pm 0.1$ and $33.0 \pm$ 0.8 , respectively, and mean chl a concentrations were $4.6 \pm 1.0$ and $3.9 \pm 0.7 \mu \mathrm{g} \mathrm{l} \mathrm{l}^{-1}$, respectively. Mean water depths and peak-to-peak tidal amplitudes at the study area were $16 \pm 15$ and $25 \pm 3 \mathrm{~cm}$, respectively. The development in bivalve bed water coverage during a tidal cycle showed that at low tide, approximately $40 \%$ of the bivalve bed was emerged $\left(\sim 4700 \mathrm{~m}^{2}\right)$ and at high tide, the bed was $100 \%$ submerged (Fig. 2). The cover and volume of water on the bivalve bed and biomass of Crassostrea gigas and Mytilus edulis in each depth interval were modeled for each hour during a tidal cycle. The results at low tide, average sea level and high tide are shown in Fig. 3.

\section{Bivalve density and shell height to dry weight relationships}

The mean density of $C$. gigas in the study area was $35 \pm 36 \mathrm{~m}^{-2}$ (118 samples; 1028 individuals), with a mean shell height of $8.4 \pm 2.4 \mathrm{~cm}$, equivalent to an individual average dry weight of $2.20 \pm 1.50 \mathrm{~g}$. The mean den sity of $M$. edulis was $1001 \pm 685 \mathrm{~m}^{-2}(118$ samples; 29519 individuals), with an average shell height of $4.1 \pm 0.5 \mathrm{~cm}$, equivalent to an individual mean dry weight of $0.31 \pm 0.07 \mathrm{~g}$. The standard deviation of the mean densities reflects the very high degree of spatial heterogeneity of both species in the study area.

Except for the linear regression on log-transformed data for C. gigas 2009 (Fig. 4A), the rest of the linear regressions fulfilled the BLUE conditions. For $C$. gigas 2009, the only criterion not met was linearity of residuals when plotted against the fitted dry weight (LOESS function). In addition, the residuals of the linear regression for M. edulis 2009 (Fig. 4C) was not normally distributed (Shapiro-Wilks statistics: $p=$ 0.003), but this is not a part of BLUE. When comparing the estimated parameters obtained from the linear regressions (on log-transformed data) with those from the non-linear regressions (on raw data), the likelihood estimates (Akaike's information criterion, AIC) showed that the linear regressions had the lowest bias on the estimated parameters compared to the non-linear regressions. In the case of C. gigas 2009, which did not fulfill the BLUE conditions, the AICnorm/AIC-log was 9.1. From the above, the linear regressions on log-transformed data were used to 


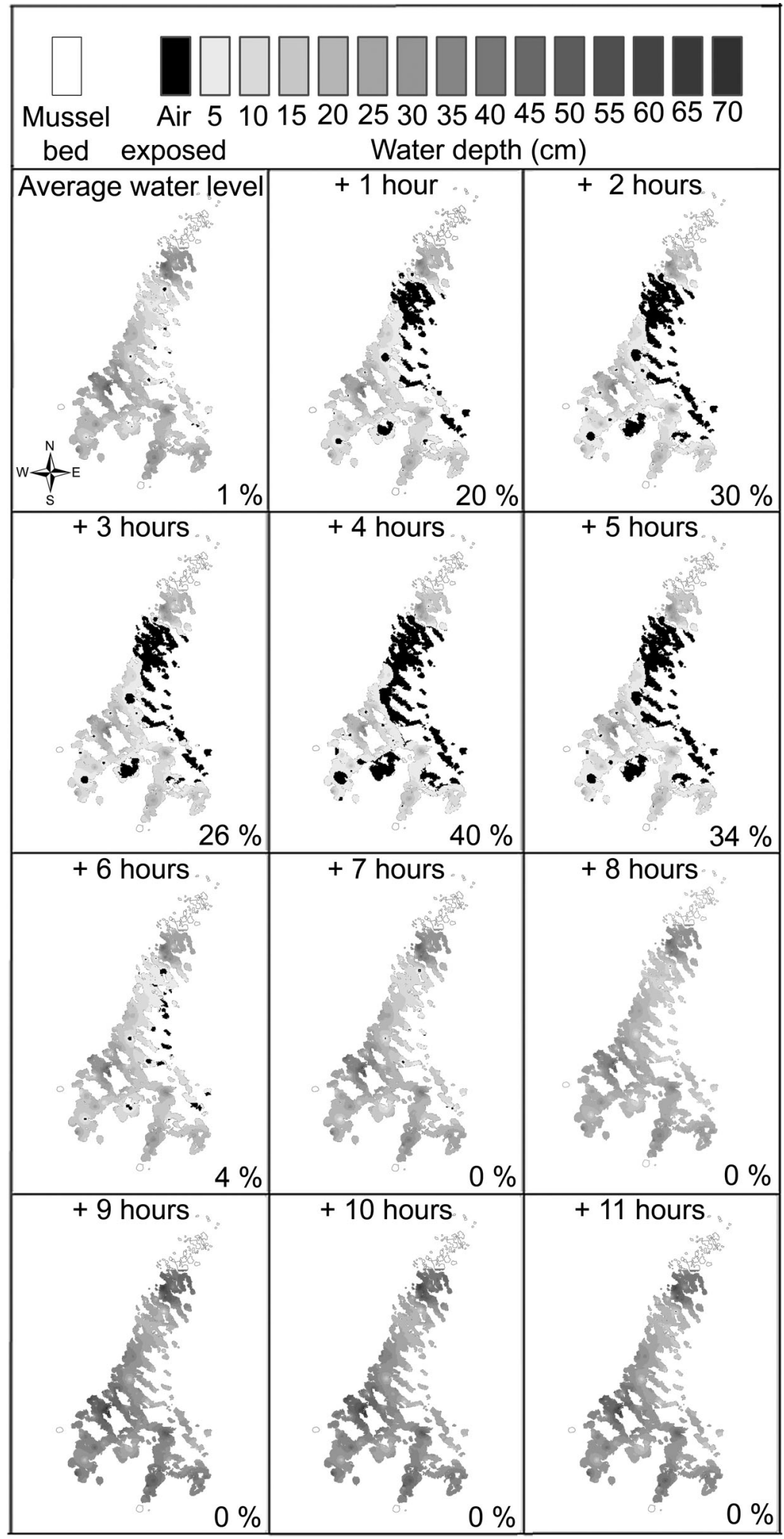

Fig. 2. Modeled temporal water coverage during a tidal cycle at Agger Tange, Limfjord, Denmark. The water coverage at $+12 \mathrm{~h}$ was equal to $+11 \mathrm{~h}$ and has been omitted. The percentage of the total bed area being exposed to air is given in the lower right corner in each panel describe the relationships between shell height and dry weight for both bivalve species and years. The slopes of the shell height-to-weight relationships of C. gigas and M. edulis (Fig. 4) were for both species significantly different between the 2 yr (t-test: $\mathrm{p}=$ $0.0001, t=3.9$, df $=206$ and $\mathrm{p}<$ $0.00001, t=5.6, \mathrm{df}=304$, respectively). The effect size of the slopes between years for $C$. gigas was medium $(D=$ 0.73 ), and for $M$. edulis, it was small $(D=0.39)$. Conversions of shell height to dry weight of soft parts in all deployments were made using the appropriate equation for the species and year.

The mean shell height of bivalves present in the deployments of the open top chamber in 2009 was $10.4 \pm 2.8 \mathrm{~cm}$ ( $\mathrm{n}=38)$ and $4.1 \pm 1.0 \mathrm{~cm}(\mathrm{n}=862)$ for C. gigas and M. edulis, respectively. In 2010 , the mean shell height in deployments was $9.2 \pm 3.7 \mathrm{~cm} \mathrm{(n=71)}$ and $3.8 \pm 1.2 \mathrm{~cm}(\mathrm{n}=1148)$ for $C$. gigas and $M$. edulis, respectively. The mean shell height between years for $C$. gigas showed a small effect size $(D=0.37)$ and was not significantly different (Mann-Whitney rank sum test: $\mathrm{p}=$ $0.28, T=2262$ ). The mean shell height for $M$. edulis between years showed a small effect size $(D=0.27)$, although it was significantly different (MannWhitney $U$-test: $\mathrm{p}<0.001, T=$ $924224)$. According to the height-toweight relationships, the mean dry weight of $C$. gigas and $M$. edulis in 2009 was $3.73 \pm 0.28$ and $0.258 \pm$ $0.008 \mathrm{~g}$, respectively. In 2010, the mean dry weight of $C$. gigas and $M$. edulis was $1.21 \pm 0.11 \mathrm{~g}$ and $0.207 \pm$ $0.017 \mathrm{mg}$, respectively.

\section{Area-specific clearance rate}

At ambient chl a concentrations $\left(2-5 \mu \mathrm{g} \mathrm{l}^{-1}\right)$, the average area-specific clearance rate was $138.6 \pm 32.7 \mathrm{l} \mathrm{h}^{-1}$ $\mathrm{m}^{-2}(\mathrm{n}=18)$ and $447.2 \pm 97.8 \mathrm{l} \mathrm{h}^{-1} \mathrm{~m}^{-2}$ ( $\mathrm{n}=16$ ) for C. gigas and M. edulis, respectively (Fig. 5). The difference in 

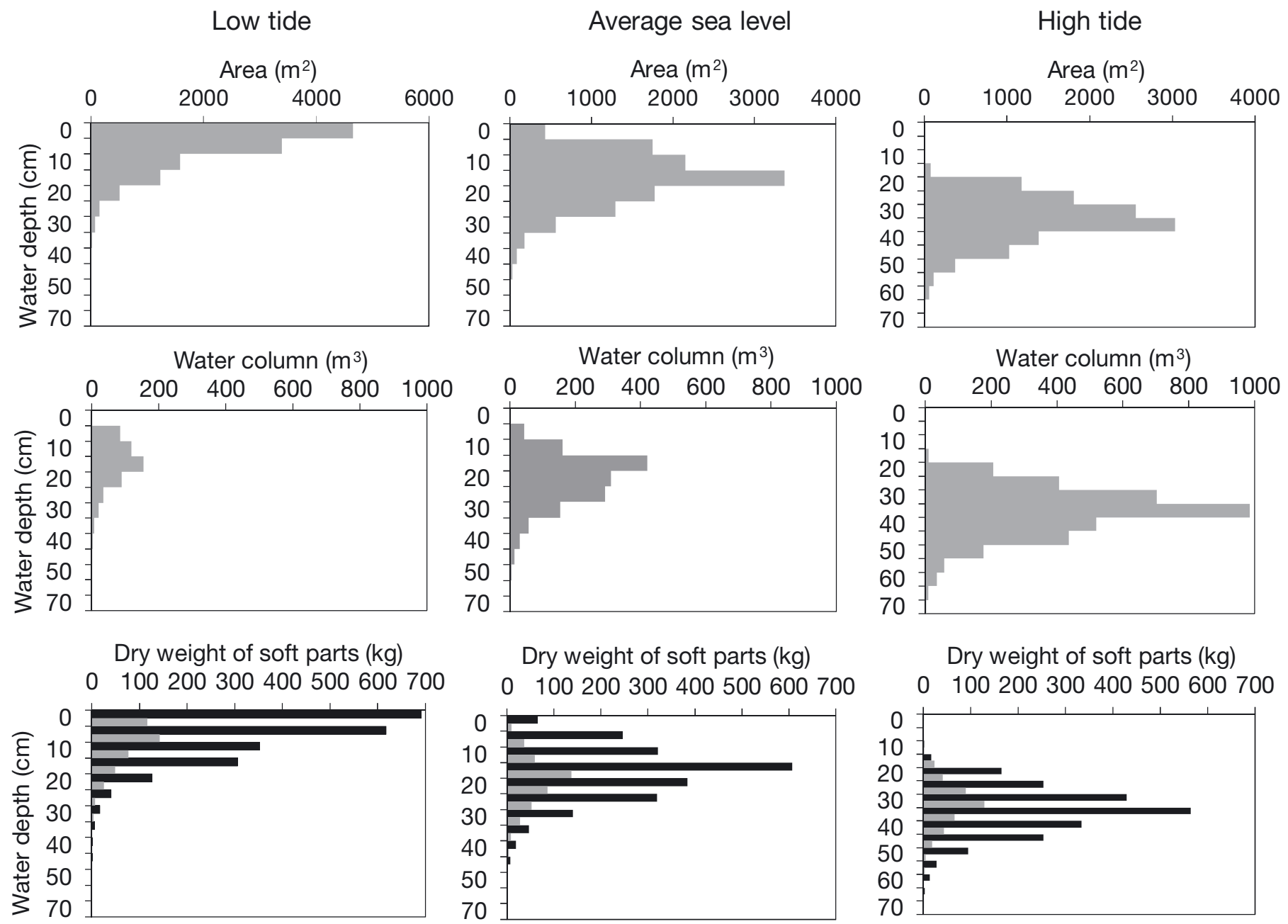

Fig. 3. Development in time and space of submerged bivalve bed area (upper panels), water column volume (middle panels) and biomass of Crassostrea gigas (grey bars) and Mytilus edulis (black bars) (lower panels) at low tide, average sea level and high tide at Agger Tange, Limfjord, Denmark

average area-specific clearance rate between C. gigas and $M$. edulis showed a large effect size $(D=4.23)$ and was significantly different (Mann-Whitney $U$-test, $T=375, \mathrm{p}=0.001$ ).

\section{Bivalve bed clearance}

The clearance rate of the bivalve bed during a tidal cycle was estimated taking into account changes in water depth, cover of submerged area and depth distribution of the 2 bivalve species (Fig. 3). The 2 species shared the same vertical distribution (Fig. 3). At high tide, the entire bivalve bed was fully submerged, and the water volume cleared by the bivalve bed was estimated at $3873 \mathrm{~m}^{3}$ $\mathrm{h}^{-1}$, of which $C$. gigas and $M$. edulis contributed 763 and $3110 \mathrm{~m}^{3} \mathrm{~h}^{-1}$, respectively (Fig. 6). At high tide, the 2 species were estimated to clear the available water column volume 1.1 times an hour (Fig. 6). At low tide, $40 \%$ of the bivalve bed was emerged, and the total clearance rate of the bed decreased to 2667 $\mathrm{m}^{3} \mathrm{~h}^{-1}$, of which $C$. gigas and $M$. edulis contributed 552 and $2115 \mathrm{~m}^{3} \mathrm{~h}^{-1}$, respectively (Fig. 6). At low tide, the entire bivalve bed was estimated to clear the overlying water column 5.2 times an hour (Fig. 6). Integrating for each hour during a tidal cycle, the bivalve bed showed a total clearance of $45838 \mathrm{~m}^{3}$, of which C. gigas and M. edulis contributed 9169 and $36669 \mathrm{~m}^{3}$, respectively. The integrated water volume available to the bivalves during the tidal cycle was estimated at $24394 \mathrm{~m}^{3}$. Thus, integrated over a tidal cycle, the 2 bivalves were estimated to clear the water volume 1.9 times, of which C. gigas and $M$. edulis contributed 0.38 and 1.5 times, respectively. 

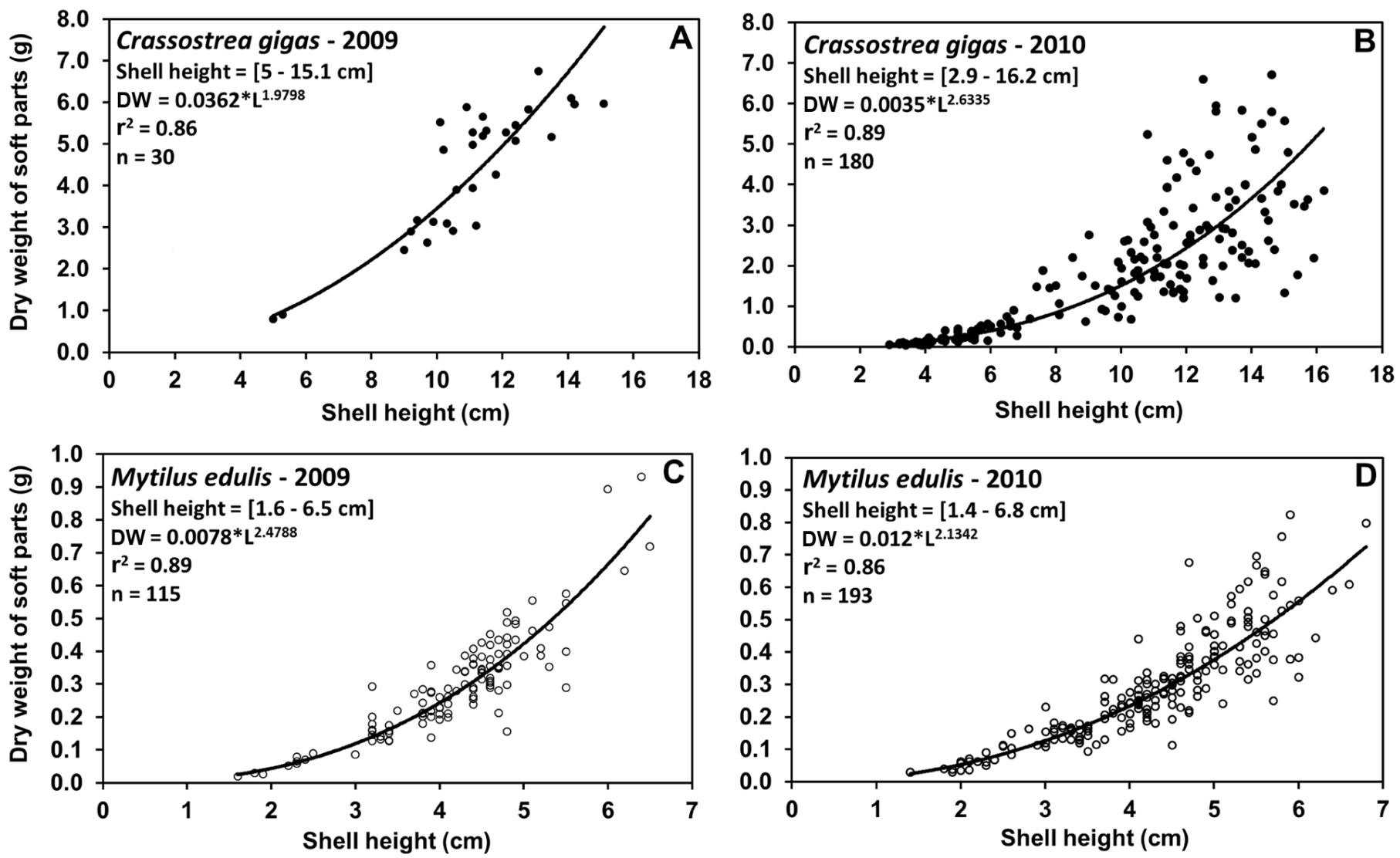

Fig. 4. (A,B) Crassostrea gigas and (C,D) Mytilus edulis dry weight (DW) of soft parts as a function of shell height (L) in 2009 and 2010 at Agger Tange, Limfjord, Denmark

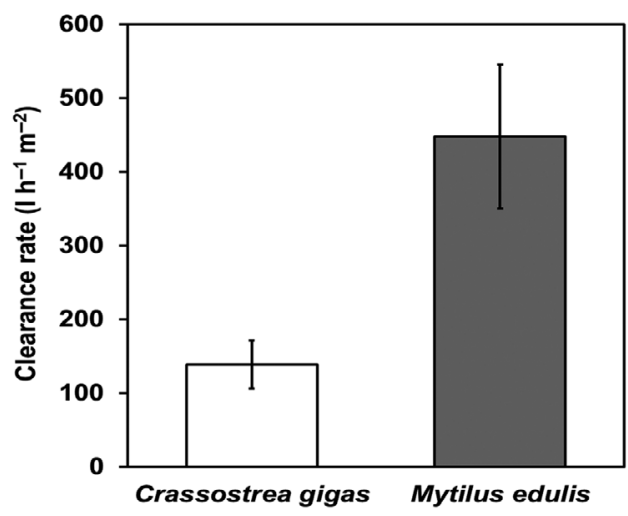

Fig. 5. Mean $\pm \mathrm{SD}$ in situ area-specific clearance rates at ambient chl a concentrations $\left(2-5 \mathrm{\mu g} \mathrm{l}^{-1}\right)$ of Crassostrea gigas $(\mathrm{n}=18)$ and Mytilus edulis $(\mathrm{n}=16)$ at Agger Tange, Limfjord, Denmark. C. gigas: density $=35$ ind. $\mathrm{m}^{-2}$, dry weight $=77 \mathrm{~g} \mathrm{~m}^{-2}(\mathrm{n}=118) ; M$. edulis: density $=1001$ ind. $\mathrm{m}^{-2}$, dry weight $=310 \mathrm{~g}$ ind. $\mathrm{m}^{-2}(\mathrm{n}=118)$

\section{DISCUSSION}

An important underlying parameter for field population clearance rates is the degree of activity of the individuals comprising the population. For popula-
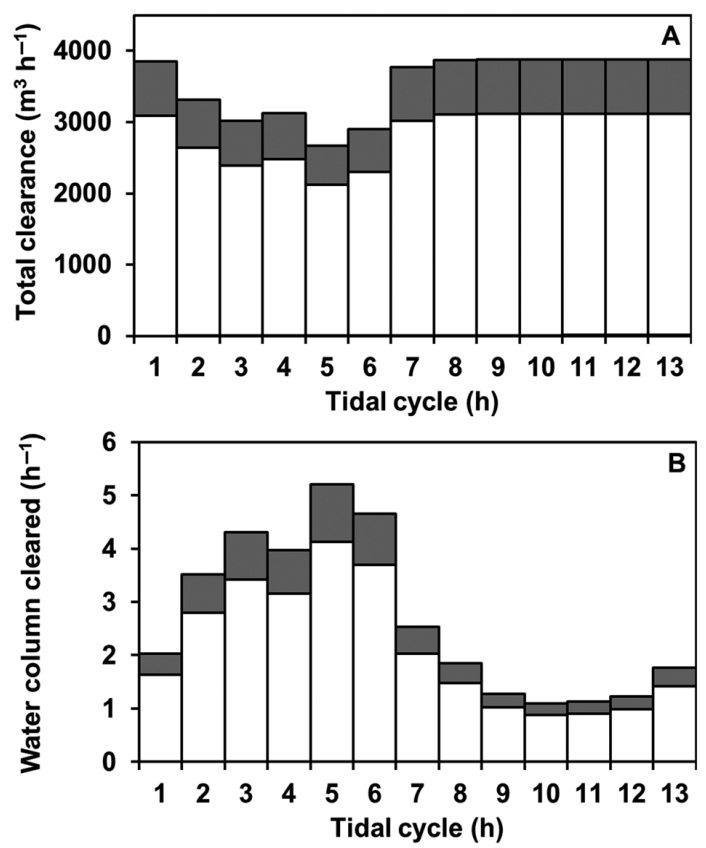

Fig. 6. (A) Total clearance and (B) the number of times the water column is cleared of a bivalve bed of co-occurring Crassostrea gigas (dark grey) and Mytilus edulis (white) during a tidal cycle at Agger Tange, Limfjord, Denmark 
tions of Mytilus edulis, field observations have shown that the proportion of the population actively clearing the water depends on the chl a concentration (Dolmer 2000b). At ambient chl a concentrations

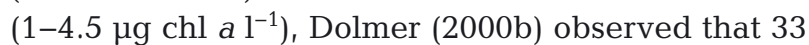
to $75 \%$ of an $M$. edulis population was actively clearing the water. For populations of Crassostrea gigas, a mean feeding time activity of $73 \%$ and a mean respiratory time activity of $97 \%$ have been reported by Haure et al. (2003), and an in situ respiratory time activity in the range of 44 to $82 \%$ has been found by Bougrier et al. (1998). Under the assumption that (1) clearance rates found in literature for the 2 species represent individual maximal rates and (2) active specimens clear the water at the maximal rate (sensu Jørgensen 1996), the active proportion of the populations in the present study can be estimated. In the case of $C$. gigas from the Marennes-Oléron basin, France, the allometric relationship between clearance rate and dry weight of soft parts at $15^{\circ} \mathrm{C}$ has been found to be $\mathrm{CR}=4.921 \mathrm{~W}^{0.535}$, where $\mathrm{W}=\mathrm{DW}$ (Bougrier et al. 1995). The mean dry weight of $C$. gigas in the present study was $2.2 \mathrm{~g}$, and according to Bougrier et al. (1995), an oyster of this size should have a clearance rate of $7.5 \mathrm{l} \mathrm{h}^{-1}$, which with the observed mean density at Agger Tange (35 ind. $\mathrm{m}^{-2}$ ) corresponds to a theoretical area-specific population clearance rate of $263 \mathrm{l} \mathrm{h}^{-1} \mathrm{~m}^{-2}$. At ambient chl a concentrations, we estimated the mean area-specific clearance rate at $\sim 139 \mathrm{l} \mathrm{h}^{-1} \mathrm{~m}^{-2}$, which corresponds to $53 \%$ of the population being active. This is in good accordance with the mean feeding time activity of $73 \%$ observed by Haure et al. (2003).

The same calculations can be made for the $M$. edulis population using the allometric relationship $\mathrm{CR}=7.45 \mathrm{~W}^{0.66}$ found by Møhlenberg \& Riisgård (1979). According to the allometric equation, $M$. edulis with the observed mean dry weight $(0.31 \mathrm{~g})$ has a mean clearance rate of $3.4 \mathrm{l} \mathrm{h}^{-1}$, which at the observed mean density (1001 ind. $\mathrm{m}^{-2}$ ) corresponds to an area-specific population clearance rate of $3443 \mathrm{l} \mathrm{h}^{-1} \mathrm{~m}^{-2}$. A similar mean area-specific population clearance rate $\left(3675 \mathrm{l} \mathrm{m}^{-2} \mathrm{~h}^{-1}\right)$ is reached when extrapolating the bed consumption rate found by Fréchette et al. (1989) to the $M$. edulis density found in the present study. At ambient chl a concentrations, we found the mean area-specific clearance rate of $M$. edulis to be $\sim 447 \mathrm{l} \mathrm{h}^{-1} \mathrm{~m}^{-2}$, which corresponds to only about $13 \%$ of the population being active. Compared to the observations made by Dolmer (2000b), the $M$. edulis activity level at ambient chl a concentrations at Agger Tange seems quite low. One possible explanation could be that Dolmer (2000b) made his obser- vation on populations situated at $7.5 \mathrm{~m}$ water depth compared to the present study, where the average water depth was merely $16 \pm 15 \mathrm{~cm}$. In such a shallow location, changes in environmental conditions (e.g. water movement, suspended inorganic particles) and depletion of phytoplankton are likely to be more frequent and to affect the population response, leading to relatively lower activity.

Depletion of phytoplankton and formation of a near-bottom concentration boundary layer above bivalve beds often occurs (Fréchette et al. 1989, Prins et al. 1997, Dolmer 2000a, Riisgård et al. 2006). To what degree the boundary layer develops depends on current speed and turbulent mixing of the water column (Lassen et al. 2006, van Duren et al. 2006). When the boundary layer is established, bivalve clearance decreases the phytoplankton concentration in the boundary layer, and when phytoplankton is depleted, the bivalves will close the valves and stop clearing the water (Dolmer 2000b, Newell et al. 2001, Riisgård et al. 2006, Strohmeier et al. 2009). At Agger Tange, both very low water depth and very low velocities prevail, and near-bed algal depletion is expected to be a common phenomenon and very likely to contribute to the observed low clearance activity of the bivalve bed. In addition, at low tide, we estimated the bivalve bed to clear the water column approximately 5 times, which we consider to be an overestimate caused by bivalve inactivity due to severe algal depletion during low tide.

The population of $C$. gigas was estimated to be far closer to realize its theoretical clearance potential than $M$. edulis and has, due to size, a higher individual feeding rate (data not shown). However, due to higher density, $M$. edulis contributed most to the overall bivalve bed clearance activity. Concerning size, it should be noted that the allometric relationships for $C$. gigas were significantly different between years (Fig. 4). Whether the difference merely reflects the relatively low number of animals included in the 2009 measurement is not known. However, it should be noted that winter 2009-2010 was harsh and with sea ice, which resulted in up to $25 \%$ mortality in the study area (Strand et al. 2012). This might potentially have affected the 2010 allometric relationship, in terms of both shell height and condition of the surviving specimens. In the present study, it was estimated that the bivalve bed cleared the available water column 1.9 times during a tidal cycle. Even though this estimate is based on fieldmeasured clearance rates combined with modelling of the changes in time and space of water depth, submerged bivalve bed area and depth distribution of 
the 2 species over a tidal cycle (Figs. $3 \& 6$ ), the overestimation for the low tide period led us to the conclusion that the available water volume was most likely cleared close to 1 time during a tidal cycle.

The above, combined with the low water depth at the study site, strongly suggests that the bivalve bed is food-limited. This is supported by Holm et al. (2015), who studied the same bivalve bed and found that the condition index of $C$. gigas at Agger Tange is in the lower range of what, for example, Diederich (2006) measured in the Wadden Sea, where C. gigas has established large populations. Therefore, Holm et al. (2015) conclude that C. gigas at Agger Tange is in a relatively poor nutritional state, which most likely reflects a limited food availability. For $M$. edulis at Agger Tange, Holm et al. (2015) suggest that the low food availability could explain the lack of spat settlement during their study period.

If our estimation of the bivalve bed clearance had only been based on the area-specific clearance rates found by the field measurements and the average water depth $(16 \mathrm{~cm})$, the $12000 \mathrm{~m}^{2}$ large bivalve bed would have been estimated to clear $91385 \mathrm{~m}^{3}$ during a tidal cycle, of which C. gigas and M. edulis would have contributed 21622 and $69763 \mathrm{~m}^{3}$, respectively. Thus, with an area of $12000 \mathrm{~m}^{2}$ and a water depth of $16 \mathrm{~cm}$, the available water volume is $1920 \mathrm{~m}^{3}$, and the bivalve bed would have been estimated to clear the water column 48 times during a tidal cycle. This clearly demonstrates that in intertidal areas, field measurements of clearance rates have to be accompanied by detailed knowledge of the spatial distribution of bivalves and the temporal development in water depth, submerged bivalve bed area and depth distribution of the bivalve species to arrive at a reliable estimate of the bivalve population impact on the water column.

\section{CONCLUSIONS}

Although the Crassostrea gigas specimens had a higher individual clearance rate and were more active than specimens of the much smaller Mytilus edulis, due to its higher abundance, the latter contributed 4 times as much to the total bivalve bed clearance. We observed a relatively low clearance of the water column by $C$. gigas and $M$. edulis in the intertidal zone of a sheltered estuary, reflecting that only a fraction of the 2 bivalve species present in the study area were actively clearing the water. We concluded that the available water volume is cleared close to 1 time during the tidal cycle. The observed low clearance is a response to low algal concentration, low turbulence and depletion of phytoplankton. This strongly suggests that all available particulate food, brought in by the tide, is utilized and that the bivalve bed in general is food-limited. The food limitation is most likely the reason why the 2 species cooccur in the area, and for C. gigas, one of the possible reasons is that it still was in the phase of establishment and had not entered an invasive phase at the time of the present investigation. Concerning the estimation of the clearance activity of the bivalve bed, it should be noted that the spatial distribution analysis performed in the present study is novel in the sense that the parameters shaping the spatial distribution of the 2 bivalve species are unknown.

The measured population clearance rates of the 2 bivalves deviated significantly from published laboratory measurements. In the field, physical conditions constantly fluctuate, and measurements made at the population level represent an overall mean value of the individuals' responses integrated for the time of measurement. In contrast, laboratory studies are typically made on individuals, which are fed monocultures of algae known to be retained with $100 \%$ efficiency. Therefore, results obtained in the field display a higher degree of variability, but distinct patterns can still be observed.

Acknowledgements. We are grateful to the consultancy firm COWI A/S for access to orthophotos and to the Danish Meteorological Institute for water level data. We are indebted to Anne B. Faarborg and Birgit Søborg for analysis of plant pigments and to Hans H. Jakobsen for data on the composition of the phytoplankton in the study area. We thank Peter G. Beninger for strengthening us on the proper statistical usage of linear regression. This work was supported by the Danish Scientific Research Council for Natural Sciences, MARINVA project no. 09-066004, and by the Danish Council for Strategic Research, MarBioShell project nos. 483-2101-07-0084 and 10-078561.

\section{LITERATURE CITED}

Bahl L (2006) Implementation of new reference systems in Denmark. In: Shaping the change. Proc 23rd Int FIG Congress, Munich, 8-13 October 2006. International Federation of Surveyors (FIG), Copenhagen

Barillé L, Prou J, Héral M, Bourgrier S (1993) No influence of food quality, but ration-dependent retention efficiencies in the Japanese oyster Crassostrea gigas. J Exp Mar Biol Ecol 171:91-106

Beadman HA, Kaiser MJ, Galanidi M, Shucksmith R, Willows RI (2004) Changes in species richness with stocking density of marine bivalves. J Appl Ecol 41:464-475

> Beninger PG (2009) Directions in bivalve feeding: introduction. Aquat Biol 6:175-180

Beninger PG, Valdizan A, Cognie B, Guiheneuf F, Decottig- 
nies P (2008) Wanted: alive and not dead: functioning diatom status is a quality cue for the suspension-feeder Crassostrea gigas. J Plankton Res 30:689-697

Boldina I, Beninger PG (2016) Strengthening statistical usage in marine ecology: linear regression. J Exp Mar Biol Ecol 474:81-91

Bougrier S, Geairon P, Deslous-Paoli JM, Bachere C, Jonquières G (1995) Allometric relationships and effects of temperature on clearance and oxygen consumption rates of Crassostrea gigas (Thunberg). Aquaculture 134: 143-154

Bougrier S, Collet B, Geairon P, Geffard O, Héral M, Deslous-Paoli JM (1998) Respiratory time activity of the Japanese oyster Crassostrea gigas (Thunberg). J Exp Mar Biol Ecol 219:205-216

Büttger H, Nehls G, Witte S (2011) High mortality of Pacific oysters in a cold winter in the North-Frisian Wadden Sea. Helgol Mar Res 65:525-532

Cloern JE (1982) Does the benthos control phytoplankton biomass in South San Francisco Bay? Mar Ecol Prog Ser 9:191-202

> Conley DJ, Kaas H, Møhlenberg F, Rasmussen B, Windolf J (2000) Characteristics of Danish estuaries. Estuaries 23: 820-837

> Coughlan J (1969) The estimation of filtering rate from the clearance of suspensions. Mar Biol 2:356-358

> Cranford PJ, Hill PS (1999) Seasonal variation in food utilization by the suspension-feeding bivalve molluscs Mytilus edulis and Placopecten magellanicus. Mar Ecol Prog Ser 190:223-239

> Dame RF, Prins TC (1997) Bivalve carrying capacity in coastal ecosystems. Aquat Ecol 31:409-421

> Dame R, Dankers N, Prins T, Jongsma H, Smaal A (1991) The influence of mussel beds on nutrients in the western Wadden Sea and eastern Scheldt estuaries. Estuaries 14: 130-138

> Diederich S (2006) High survival and growth rates of introduced Pacific oysters may cause restrictions on habitat use by native mussels in the Wadden Sea. J Exp Mar Biol Ecol 328:211-227

> Diederich S, Nehls G, van Beusekom JEE, Reise K (2005) Introduced Pacific oysters (Crassostrea gigas) in the northern Wadden Sea: invasion accelerated by warm summers? Helgol Mar Res 59:97-106

> Dolmer P (2000a) Algal concentration profiles above mussel beds. J Sea Res 43:113-119

> Dolmer P (2000b) Feeding activity of mussels Mytilus edulis related to near-bed currents and phytoplankton biomass. J Sea Res 44:221-231

> Dupuy C, Vaquer A, Lam-Höai T, Rougier C and others (2000) Feeding rate of the oyster Crassostrea gigas in a natural planktonic community of the Mediterranean Thau Lagoon. Mar Ecol Prog Ser 205:171-184

Fréchette M, Butman CA, Geyer WR (1989) The importance of boundary-layer flows in supplying phytoplankton to the benthic suspension feeder, Mytilus edulis L. Limnol Oceanogr 34:19-36

Gili JM, Coma R (1998) Benthic suspension feeders: their paramount role in littoral marine food webs. Trends Ecol Evol 13:316-321

> Grizzle RE, Greene JK, Luckenbach MW, Coen LD (2006) A new in situ method for measuring seston uptake by suspension-feeding bivalve mollusks. J Shellfish Res 25: 643-649

> Hammer Ø, Harper DAT, Ryan PD (2001) PAST: paleonto- logical statistics software package for education and data analysis. Palaeontol Electronica 4:art4

> Hansen BW, Dolmer P, Vismann B (2011) In situ method for measurements of community clearance rate on shallow water bivalve populations. Limnol Oceanogr Methods 9: 454-459

Haure J, Huvet A, Palvadeau H, Nourry M, Penisson C, Martin JLY, Boudry P (2003) Feeding and respiratory time activities in the cupped oyster Crassostrea gigas, Crassostrea angulata and their hybrids. Aquaculture 218:539-551

Holm MW, Davids JK, Dolmer P, Vismann B, Hansen BW (2015) Moderate establishment success of Pacific oyster, Crassostrea gigas, on a sheltered intertidal mussel bed. J Sea Res 104:1-8

Holm MW, Davids JK, Dolmer P, Holmes E, Nielsen TT, Vismann B, Hansen BW (2016) Coexistence of Pacific oyster Crassostrea gigas (Thunberg, 1793) and blue mussels Mytilus edulis Linnaeus, 1758 on a sheltered intertidal bivalve bed? Aquat Invasions 11:155-165

Jensen KR, Knudsen J (2005) A summary of alien marine benthic invertebrates in Danish waters. Oceanol Hydrobiol Stud 34:137-162

Jørgensen CB (1996) Bivalve filter feeding revisited. Mar Ecol Prog Ser 142:287-302

Koseff JR, Holen JK, Monismith SG, Cloern JE (1993) Coupled effects of vertical mixing and benthic grazing on phytoplankton populations in shallow, turbid estuaries. J Mar Res 51:843-868

Kristensen PS, Borgstrøm R (2005) The Danish Wadden Sea; fishery of mussels (Mytilus edulis L.) in a wildlife reserve? In: Laursen $\mathrm{K}$ (ed) Monitoring and assessment in the Wadden Sea. Proc 11th Int Sci Wadden Sea Symp, Esbjerg, 4-8 April 2005. NERI Tech Rep 573, p 113-122

> Lassen J, Kortegård M, Riisgård HU, Friederichs M, Graf G, Larsen PS (2006) Down-mixing of phytoplankton above filter-feeding mussels-interplay between water flow and biomixing. Mar Ecol Prog Ser 314:77-88

Markert A, Wehrmann A, Kröncke I (2010) Recently established Crassostrea-reefs versus native Mytilus-beds: differences in ecosystem engineering affects the macrofaunal communities (Wadden Sea of Lower Saxony, southern German Bight). Biol Invasions 12:15-32

Mo C, Neilson B (1994) Standardization of oyster soft tissue dry weight measurements. Water Res 28:243-246

Møhlenberg F (1995) Regulation mechanisms of phytoplankton growth and biomass in a shallow estuary. Ophelia 42: 239-256

Møhlenberg F, Riisgård HU (1978) Efficiency of particle retention in 13 species of suspension feeding bivalves. Ophelia 17:239-246

Møhlenberg F, Riisgård HU (1979) Filtration rate, using a new indirect technique, in 13 species of suspensionfeeding bivalves. Mar Biol 54:143-147

Nehls G, Diedrich S, Thieltges DW, Strasser M (2006) Wadden Sea mussel beds invaded by oysters and slipper limpets: competition or climate control? Helgol Mar Res 60:135-143

Nehls G, Witte S, Büttger H, Dankers N and others (2009) Beds of blue mussels and Pacific oysters. Thematic Report No. 11. In: Marencic H, de Vlas J (eds) Quality status report 2009. Wadden Sea Ecosystem No. 25. Common Wadden Sea Secretariat, Trilateral Monitoring and Assessment Group, Wilhelmshaven

Nehring S (2006) NOBANIS - invasive alien species fact 
sheet. Crassostrea gigas

Newell CR, Wildish DJ, MacDonald BA (2001) The effects of velocity and seston concentration on the exhalant siphon area, valve gap and filtration rate of the mussel Mytilus edulis. J Exp Mar Biol Ecol 262:91-111

Pales Espinosa E, Hasan D, Ward JE, Shumway SE, Allan B (2010) Role of epicellular molecules in the selection of particles by the blue mussel, Mytilus edulis. Biol Bull 218:50-60

> Petersen JK, Bougrier S, Smaal AC, Garen P, Robert S, Larsen JEN, Brummelhuis E (2004) Intercalibration of mussel Mytilus edulis clearance rate measurements. Mar Ecol Prog Ser 267:187-194

Pouvreau S, Body A, Buestel D (2000) In situ suspension feeding behaviour of the pearl oyster Pinctada margaritifera: combined effects of body size and weather-related seston composition. Aquaculture 181:91-113

$>$ Prins TC, Smaal AC, Pouwer AJ, Dankers N (1996) Filtration and resuspension of particulate matter and phytoplankton on an intertidal mussel bed in the Oosterschelde estuary (SW Netherlands). Mar Ecol Prog Ser 142:121-134

Prins TC, Smaal AC, Dame RF (1997) A review of the feedbacks between bivalve grazing and ecosystem processes. Aquat Ecol 31:349-359

Reise K (1998) Pacific oysters invade mussel beds in the European Wadden Sea. Senckenb Marit 28:167-175

Reise K, Olenin S, Thieltges DW (2006) Are aliens threatening European aquatic coastal ecosystems? Helgol Mar Res 60:77-83

Riisgård HU (1991) Filtration rate and growth in the blue mussel, Mytilus edulis Linneaus, 1758: dependence on algal concentration. J Shellfish Res 10:29-35

> Riisgård HU (2001) On measurement of filtration rates in bivalves - the stony road to reliable data: review and interpretation. Mar Ecol Prog Ser 211:275-291

- Riisgård HU, Møhlenberg F (1979) An improved automatic recording apparatus for determining the filtration rate of Mytilus edulis as a function of size and algal concentration. Mar Biol 52:61-67

Riisgård HU, Randløv A (1981) Energy budgets, growth and filtration rates in Mytilus edulis at different algal concentrations. Mar Biol 61:227-234

- Riisgård HU, Lassen J, Kittner C (2006) Valve-gape response times in mussels (Mytilus edulis) - effects of laboratory preceding-feeding conditions and in situ tidally induced variation in phytoplankton biomass. J Shellfish Res 25:901-911

Riisgård HU, Lassen J, Kortegaard M, Møller LF, Friedrichs M, Jensen MH, Larsen PS (2007) Interplay between filter-feeding zoobenthos and hydrodynamics in the shallow Odense Fjord (Denmark)-earlier and recent studies, perspectives and modeling. Estuar Coast Shelf Sci 75:281-295

Saurel C, Gascoigne JC, Palmer MR, Kaiser MJ (2007) In situ mussel feeding behavior in relation to multiple environmental factors: regulation through food concentration and tidal conditions. Limnol Oceanogr 52:1919-1929

Seed R (1976) Ecology. In: Bayne BL (ed) Marine mussels: their ecology and physiology. Cambridge University Press, Cambridge, p 13-65

Editorial responsibility: Peter Beninger, Nantes, France
Shumway SE, Cucci TL, Newell RC, Yentsch CM (1985) Particle selection, ingestion and absorption in filter-feeding bivalves. J Exp Mar Biol Ecol 91:77-92

Strand Å, Blanda E, Bodvin T, Davids JK and others (2012) Impact of an icy winter on the Pacific oyster (Crassostrea gigas Thunberg, 1793) populations in Scandinavia. Aquat Invasions 7:433-440

Strickland JDH, Parsons TT (1972) A practical handbook of seawater analysis, 2nd edn. Fish Res Bd Can Bull 167, Ottawa

Strohmeier T, Strand Ø, Cranford P (2009) Clearance rates of the great scallop (Pecten maximus) and blue mussel (Mytilus edulis) at low natural seston concentrations. Mar Biol 156:1781-1795

Strohmeier T, Strand $\varnothing$, Alunno-Bruscia M, Duinker A, Cranford PJ (2012) Variability in particle retention efficiency by the mussel Mytilus edulis. J Exp Mar Biol Ecol 412:96-102

Troost K (2010) Causes and effects of a highly successful marine invasion: case-study of the introduced Pacific oyster Crassostrea gigas in continental NW European estuaries. J Shellfish Res 64:145-165

> Troost K, Stamhuis EJ, van Duren LA, Wolff WJ (2009) Feeding current characteristics of three morphologically different bivalve suspension feeders, Crassostrea gigas, Mytilus edulis and Cerastoderma edule, in relation to food competition. Mar Biol 156:355-372

> van de Koppel J, Gascoigne JC, Theraulaz G, Rietkerk M, Mooij WM, Herman PMJ (2008) Experimental evidence for spatial self-organization and its emergent effects in mussel bed ecosystems. Science 322:739-742

> van Duren LA, Herman PMJ, Sandee AJJ, Heip CHR (2006) Effects of mussel filtering activity on boundary layer structure. J Sea Res 55:3-14

$>$ Vismann B (1990) Field measurements of filtration and respiration in Mytilus edulis L. an assessment of methods. Sarsia 75:213-216

> Walne PR (1972) Influence of current speed, body size and water temperature on filtration rate of five species of bivalves. J Mar Biol Assoc UK 52:345-374

- Ward JE, Shumway SE (2004) Separating the grain from the chaff: particle selection in suspension- and depositfeeding bivalves. J Exp Mar Biol Ecol 300:83-130

Wasmund N, Topp I, Schories D (2006) Optimising the storage and extraction of chlorophyll samples. Oceanologia 48:125-144

- Wehrmann A, Herlyn M, Bungenstock F, Hertweck G, Millat G (2000) The distribution gap is closed-first record of naturally settled Pacific oysters Crassostrea gigas in the East Frisian Wadden Sea, North Sea. Senckenb Marit 30:153-160

Williams LG (1982) Mathematical analysis of the effects of particle retention efficiency on determination of filtration rate. Mar Biol 66:171-177

- Wrange AL, Valero J, Harkestad LS, Strand $\varnothing$ and others (2010) Massive settlements of the Pacific oyster, Crassostrea gigas, in Scandinavia. Biol Invasions 12:1453-1458

Xiao X, White EP, Hooten MB, Durham SL (2011) On the use of log-transformation vs. nonlinear regression for analyzing biological power laws. Ecology 92:1887-1894 